\title{
Ordu kenti kıyı rekreasyon alanlarında yer alan donatı elemanları üzerine bir araștırma
}

\author{
Pervin YEŞiL' ${ }^{1}$ Elif ŞATIROĞLU ${ }^{1}$ \\ ${ }^{1}$ Ordu Üniversitesi, Ziraat Fakültesi, Peyzaj Mimarlığı Bölümü, Ordu
}

Alınış tarihi: 6 Kasım 2018, Kabul tarihi: 28 Mayıs 2019

Sorumlu yazar: Pervin YEŞiL, e-posta: perviny48@gmail.com

\section{$\ddot{0} \mathbf{z}$}

Donatı elemanları kentsel mekanların vazgeçilmez öğelerinden olup, onlara anlam ve işlev kazandıran unsurlardır. $\mathrm{Bu}$ çalışmada Ordu kent merkezini doğudan batıya kateden ve kentin en önemli rekreasyon alanlarını bünyesinde barındıran kıyısal alan kullanımları içerisinde yer alan donatı elemanları incelenmiștir. Bu kapsamda 280 kullanıcı ile birebir anket çalışması yürütülmüștür. Anket çalışmasında kullanıcıların donatı elemanlarını işlevsellik, sağlamlık, estetik, güvenlik, bakım, kullanım rahatlığı, çevreye uyum ve kent imajına katkı kriterleri açısından değerlendirmeleri istenmiştir. Çalışma sonucunda kullanıcıların Genel Memnuniyet Düzeyleri 'orta-iyi' olarak tespit edilmiştir. Çalışma sonucunda elde edilen veriler ışığında öneriler sunulmuştur.

Anahtar kelimeler: Donatı elemanları, Rekreasyon alanları, Ordu

\section{A research on equipment elements in the coastal recreation areas of Ordu city}

\begin{abstract}
Equipment elements are indispensable elements of urban spaces and they give them meaning and function. In this study, the equipment elements within the coastal areas that contain the most important recreation areas of the city were investigated. In this context, a survey study was conducted with 280 users. In the survey study, the users were asked to evaluate the equipment elements in terms of functionality, durability, aesthetics, safety, maintenance, ease of use, adaptation to the environment and contribution to urban image. As a result of the study, the General Satisfaction Levels of the users were determined as
\end{abstract}

"medium-good". According to the data obtained from the study suggestions are presented.

Key words: Outdoor furniture, Recreational Areas, Ordu

\section{Giriş}

Kentlerin yerleşim dokusunu oluşturan yapılanmış ve yapılanmamıș alanlar 'Kentsel Mekan'ı oluşturur. Genelde kentsel mekan insanın yaşamı ile ilgili barınma-çalışma-eğlenme/dinlenme ve ulaşım gibi dört ana işlevin gerçekleștirildiği mekanlar bütünüdür (Çubuk, 1991). Kentsel mekânın yaşanabilirliği, tasarımcının kullanıcılarının beklentilerine cevap verebilme yeteneği ile belirlenir (Ylldızcl, 2001). Kentsel mekanlarda yapı yoğunluğunun baskısı ancak yapılar dişında kalan açılk ve yeşil alan varlığının doğru, dengeli ve fonksiyonel kullanımı sayesinde azaltılabilmektedir. Bu kullanım açık ve yeșil alanların sahip olduğu canlı ve cansız donatıların olumlu kullanımları sayesinde rahatlıkla sağlanabilmektedir. Bir kentin genel karakterini, mimari yapılar, açık-yeşil alanlar ve bunların birbirleriyle olan ilişkileri ve bütünlüğü tayin eder. Açık-yeşil alanlar, insan ile doğa arasındaki bozulan ilişkiyi dengelemede ve kentsel yaşam koşullarının iyileștirilmesinde önemli bir konuma sahiptir. Bu nedenle gelişmiş ülkelerde açıkyeșil alanların nitelik ve nicelikleri, medeniyetin ve yaşam kalitesinin bir göstergesi olarak kabul edilmektedir. Bu kapsamda pek çok gelișmiş ülke, insanların zihinsel ve fiziksel ihtiyaçlarını göz önünde bulundurarak insan yaşamı için uygun kent mekanı veya ekolojisini planlama ve oluşturma çabasına yönelmektedirler (Gül ve Küçük, 2001). Kentsel mekânlarda yer alan kentsel donatı elemanlarının her biri birer kullanım ve iletişim nesnesi olarak değerlendirilmektedir. Aynı zamanda birer görsel obje olarak da tanımlanan kent 
mobilyaları, kent kimliğinin bir parçası olarak nitelendirilmekte; özel bir tasarım ürünü olma özellikleri ve yer aldıkları kentsel mekân ile ilişkileri açısından ele alınmaktadırlar. Tasarlanmış, karmaşa yaratmayan, teknik açıdan yeterli, birbirleri ve bulundukları çevre ile doğru ilişkiler kuran, bu şekilde yer aldıkları mekânı tanımlayan ve doğru mesajlar aktaran kent mobilyaları olumlu elemanlar olarak kabul edilmektedir (Bayraktar vd., 2007). Kent mobilyaları kentsel yaşam kalitesinin artırılmasında ve açık alan kullanıcılarının bu alanlardaki yaşam süresinin artırılmasında oldukça önemlidir (Çoban, 2014). Kent mobilyaları, insanın kent dokusu içindeki bireysel ve toplumsal yaşamını kolaylaştıran, bireyler arası iletişimi sağlayan, mekâna işlevsel ve estetik açıdan belirli bir anlam kazandıran, değişik nitelik ve niceliklerde olan, mekânı tanımlayan ve tamamlayan niteliklerdir, objelerdir. Bu nedenle sadece işlevsel amaçlarla değil, kent peyzajını canlandırıcı etkileri açısından da büyük önem taşımaktadırlar (Bulut ve ark., 2008). Kent mobilyaları kentlerde yaşayan insanların konfor düzeyini önemli ölçüde etkilemektedir (ShaJun ve ark., 2005; Bulut vd., 2007). Kent kimliğine dayanan, onun ayırıcı öğelerinden biri olan ve destekleyen bir sistemin parçası olarak, kent mobilyalarının hem teknik, hem de görsel açıdan kent içinde süreklilik göstermesi zorunludur. $\mathrm{Bu}$ süreklilik, salt bir sistemin parçası olduğu için değil, herkes tarafından anlaşlabilir ve kullanılabilir olmayı gerektiren bir 'dil' özelliği taşımasındandır. 0 halde kent mobilyaları için yüklendikleri işlevsel görevlerin yanı sıra kent kimliği ile ilişkileri açısından, kentin anlamsal, simgesel boyutunu oluşturduklarını söylemek doğru bir yargı olacaktır (Bayrakçı, 1991). Bu çalışmada Ordu kenti kıyı rekreasyon alanlarında yer alan donatı elemanlarının mevcut durumu ve kullanıcı memnuniyet düzeyleri belirlenerek, değerlendirilmesi amaçlanmıștır.

\section{Materyal ve Yöntem}

Ordu ili, Karadeniz Bölgesi Doğu Karadeniz bölümünde yer almakta olup, kuzeyde Karadeniz, güneyde Sivas ve Tokat, batıda Samsun, doğuda ise Giresun illeri ile çevrelenmektedir. Ordu Kent makroformu, kuzeyinde Karadeniz ve güneyinde uzanan dağlık ve yamaçlık alanlar ile kenti dik keserek Karadeniz'e ulașan dört adet akarsu tarafından şekillendirilmiștir. Kentin kuzeyi boyunca Karadeniz'e paralel olarak uzayan kıyı şeridi bu akarsularla parçalanmış ve hareketlenmiștir.
Araştırmanın materyalini Ordu Kent merkezi kıyl rekreasyon alanlarında yer alan kent mobilyaları oluşturmaktadır. Araştırmaya konu olan, rekreasyon alanlarının oluşturulduğu kıyı alanının uzunluğu 4.857 km'dir.

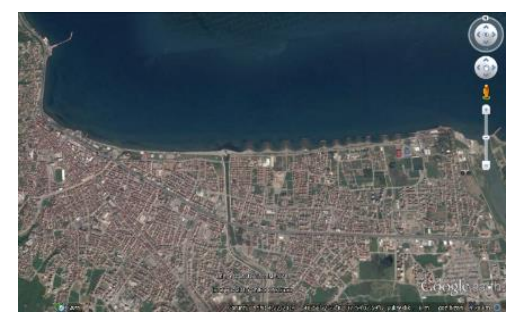

Şekil 1. Çalışma alanı

Çalışmada öncelikle alanda yapılan gözlem ve incelemeler ile mevcut kent mobilyaları tespit edilmiştir. Daha sonra bu mobilyalar işlevsellik, sağlamlık, estetik, güvenlik, bakım, kullanım rahatlı̆̆ı, çevreye uyum ve kent imajına katkı kriterleri açısından değerlendirmeye tabi tutulmuştur. Değerlendirme yapılırken, alanın kullanıcıları ile birebir anket çalışması yürütülmüştür. Döşemeler, aydınlatma elemanları, açık oturma elemanları, çöp kutuları, bilgilendirme ve yönlendirme levhaları, heykel ve plastik objeler, pergolalar, çiçeklikler ve piknik masaları çalışma kapsamında, yukarıda sözü edilen kriterler ışığında değerlendirilmiştir. Kullanıcılardan kent mobilyalarını tek tek işlevsellik, sağlamlık, estetik, güvenlik, bakım, kullanım rahatlı̆̆ı, çevreye uyum ve kent imajına katkı kriterleri açısından değerlendirmeleri ve puanlamaları istenmiştir. Puanlamalar, 1- çok kötü, 2- kötü, 3- orta, 4- iyi, 5çok iyi olacak şekilde sıralanmıştır. Anketin hazırlanmasında ve uygulanmasında Erdoğan ve ark., (2011)'ın çalışmasından yararlanılmıştır. Ordu kent nüfusu 205.396 kişidir (ADNKS, 2017). Binde bir örnekleme yöntemi ile minimum 205 kişi ile anket çalışması yürütülmesi uygun olacağı tezinden hareketle toplam 280 kullanıcı ile anket çalışması yürütülmüştür. Kullanıcıların her mobilyaya atanan kriterlere verdiği puan ortalamaları alınarak genel memnuniyet düzeyi değerlendirilmiştir. Kullanıcıların yaş, meslek ve gelir düzeyleri ile kent mobilyaları ile ilgili memnuniyetlerini karşılaștırmak amacı ile Tukey testi, cinsiyet faktörü için ise T Testi uygulanmıștır. Yapılan testler ortalama puanlar üzerinden hesaplanmıştır. Tüm hesaplamalar SPSS v24 istatistik paket programı ile yapılmıştır.

\section{Bulgular}

Ordu kenti kuzeyinden denize paralel bir konumda bulunmakta olup; kıyı tüm kenti doğudan batıya kat 
etmektedir. Ordu kenti kıyı rekreasyon alanları, kentte yer alan irili ufaklı mahalle parklarının ötesinde en önemli rekreasyon alanı olarak nitelendirilebilir. Aslında alan tümü ile değerlendirildiğinde kentin yegane kent parkı durumundadır. $\mathrm{Bu}$ alanlar aralarından geçen akarsularla bölünmüş olup, her akarsu farklı bir kullanım alanını bitirmekte ve diğer kullanımı başlatmaktadır. $\mathrm{Bu}$ bağlamda kıyı rekreasyon alanları Civil ve Bülbül dereleri tarafından kesilen üç bölüme ayrılabilir. Kıyı șeridinin rekreasyonel açıdan kullanılabilir kesimi Durugöl mahallesinde Org. İbrahim Fırtına Bulvarı ile başlamaktadır. Bu kesim, bir baștan diğer başa kadar yürüme ve gezinti yolları ile güzergâh boyunca yer alan piknik masaları ve üstü kapalı ya da açı oturma elemanları ile donatılmıştır. İkinci kısım Mehmetçik Bulvarı üzerinde yer alan Tayfun Gürsoy Parkı olup, yürüme ve gezinti için oluşturulmuş geniş yollar, kıyıda yer alan seyir amaçlı açık oturma birimleri, geniş yeşil alanlar ve çok sayıda çocuk oyun alanının bulunduğu çok fonksiyonlu bir alandır. Üçüncü kısım Boztepe bağlantısını oluşturan Teleferik istasyonunun bulunduğu Atatürk Bulvarı'ndan bașlamaktadır. Bu noktada çeşitli açık ve kapalı oturma alanları, meydan, gezinti yollarına yer verilmiş olup; güzergâh batıda iskelenin bulunduğu bölge ile son bulmaktadır. Alanda yer alan kent mobilyaları incelendiğinde genellikle birbirine benzer mobilyalar kullanıldığı görülmektedir. Dolayısı ile bu çalışma ve çalışma kapsamında yürütülen ankette kıyı rekreasyon alanları bir bütün olarak düşünülerek kurgulanmıştır. Çalışma alanında yer alan döşemeler çeşitlilik göstermektedir. Beton, ahşap, kilit parke ve Arnavut taşı döşeme elemanlarını olușturan temel materyallerdir. Genel olarak döșemelerin sağlam ve bakımlı olduğu görülmesine karşın, bazı noktalarda tahripler ve fonksiyonu etkileyen bozulmalar gözlenmiştir. Ayrıca oldukça yoğun bir kullanıma ve sirkülasyona sahip olan teleferik istasyonu bölgesinde kullanılan Arnavut taşı döşemenin hareketi kısıtladığı ve yürüme zorluğuna neden olduğu görülmektedir. Tüm kıyı boyunca genellikle orta boylu aydınlatma elemanları birbirlerine benzer nitelikler sergilemekte, aydınlatma işlevi ve donatı niteliği açısından kesintiye uğramadan küçük farklılıklarla konumlandırılmaktadır. Özellikle çocuk oyun alanlarının bulunduğu bazı noktalarda spot aydınlatmalar ile ortamlar daha aydınlık hale getirilmiştir. Aydınlatma elemanlarında yer yer bozulmalar tespit edilmiş, gece görüşü açısından da işlevsel noksanlıklar ve kör noktalar olduğu görülmüştür. Tüm kıyı boyunca yer alan açık oturma elemanları için genellikle ahşap, ahşap-beton malzeme kullanılmıștır. Arkalıklı ve arkalıksız banklar, dairesel oturma birimleri, ağaç altı oturma birimleri, açık oturma elemanlarını oluşturmaktadır. Yağışın egemen olduğu iklim koşulları göz önüne alındığında kısmen yıpranmaların gözlendiği bazı oturma elemanları bakıma ihtiyaç duymaktadır. Ahşap pergolalar ve plastik tenteler tarafından temsil edilen örtü elemanları, kıyı boyunca yer yer konumlandırılmış durumdadır. Alanla malzeme bakımından oldukça bütünleşmiş bulunan ahşap pergolaların üzeri çok seyrek latalarla kaplıdır. Aslında pergolaların yağmur ve güneşten koruma gibi fonksiyonel özellikler sergilemediği, özel mekânlar oluşturma ve mekâna estetik değer katma anlamında işlevli olduğu görülmektedir. Tenteler ise mevcut doku ile fazlaca uyumlu olmasa da yer yer mekâna hareket kazandırmada etkili olmasının yanı sıra, yağmur ve güneşten korunma anlamında da işlevsellik kazandırmıştır. Beton, beton-ahşap ve metal konstrüksiyonlu çöp kutuları ise kıyı boyunca oldukça sık bir șekilde yer almaktadır. Yürüme yollarının etrafında ve oturma birimlerinin yakınlarında konumlandırılmış olan çöp kutuları miktar olarak yeterli görülmektedir. Oldukça yağıșlı olan yörede tümü açık olan çöp kutularının içlerinin suyla dolmasına neden olmaktadır. Bilgilendirme ve yönlendirme levhaları genellikle teleferik istasyonu bölgesinde yer almaktadır. Oldukça yeterli olan bu kent mobilyalarına diğer bölgelerde neredeyse hiç rastlanmamaktadır. Tarihi nitelikli heykeller, güneş saati ve yer yer tamamı beyaz olan plastikler, çalışma alanının heykel ve plastik objelerini oluşturmaktadır (Şekil 2). Alanda banklarla kombine edilen ve yer yer de fidan dikilerek değerlendirilen çiçeklikler kullanılmıştır. Fidan dikilerek bitki kasası işlevi kazandırılmaya çalışılan çiçeklikler, oldukça estetik ve fonksiyonel gibi görünmesine rağmen bu amaç için oldukça küçüktür ve ağaçların büyümesi için uygun değildir. Piknik masaları kıyı şeridinin doğu kesiminde oldukça sık konumlandırılmıștır. Özellikle yaz aylarında oldukça yoğun kullanıma olanak tanımaktadır. Ancak yürüyüş yollarının paralelinde konumlandırılmaları nedeni ile aktif ve pasif kullanımların yoğun şekilde bir araya gelmesi karmaşaya yol açmaktadır. Yapılan gözlemlerin yanı sıra kullanıcılara uygulanan anket çalışmasında öncelikle cinsiyet, yaş, meslek ve gelir durumları ortaya konulmuştur. 


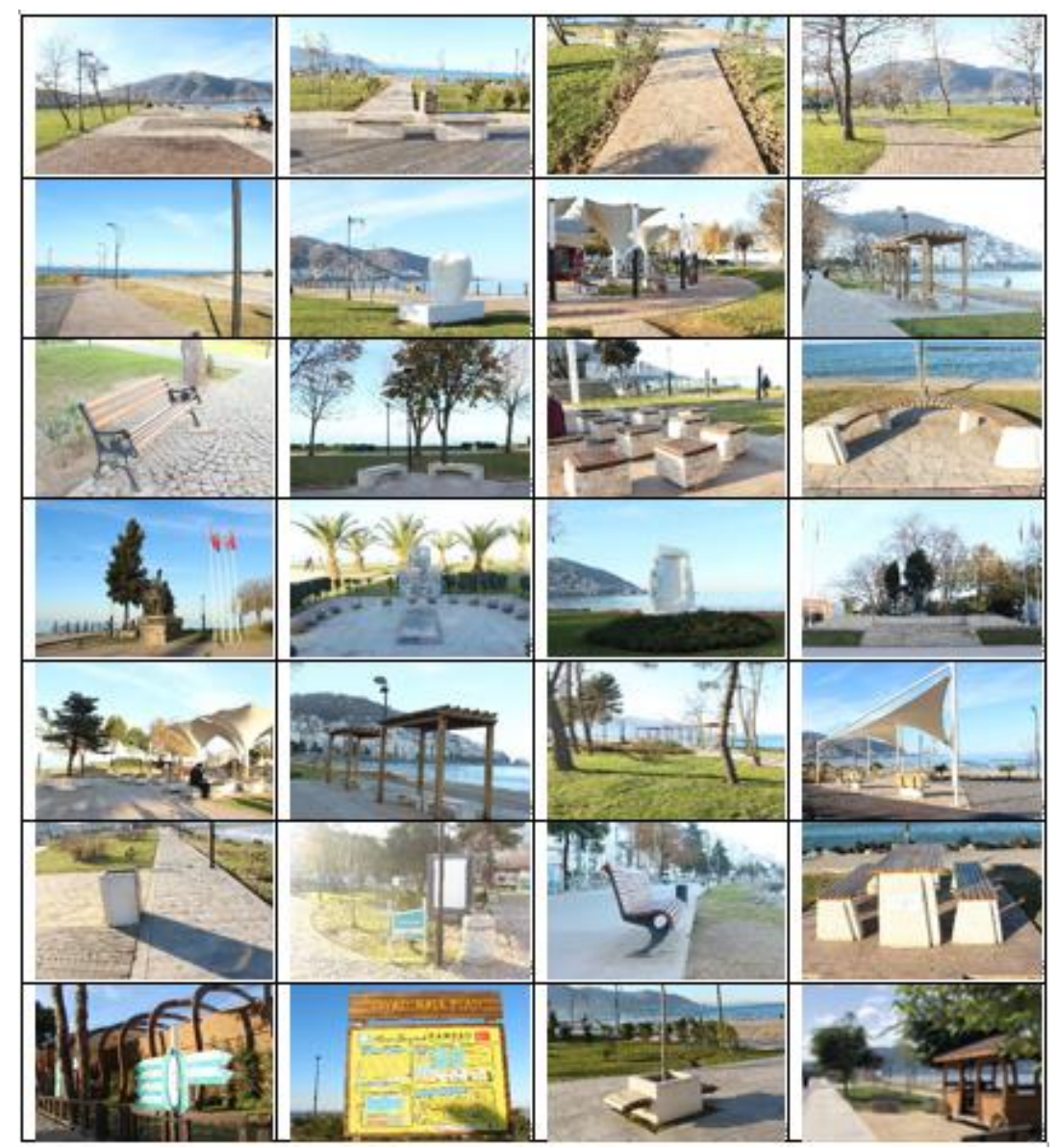

Şekil 2. Alanda yer alan donatı elemanlarından örnekler

Bulgulara göre deneklerin \% 50'si erkek, \% 50'si kadın olup, \%42.1'i 17-24, \%27.5'i 25-36, \%14.3'ü 37-45, \%10.4'ü 45-55, \%4.3'ü 56-65 ve \%1.4'ü 65 ve üstü yaş gruplarındadırlar. Meslek durumu; \%43.1 öğrenci, \%12.1 memur, \%6.4 işçi, \%6.4 işsiz, \%6.8 emekli, \%8.2 ev hanımı, \%16.1 ise özel sektördür. Deneklerin gelir durumlarına göre ise; \%45.7 1.000TL ve altı, \%29.3 1.001-2.000TL, \%21.4 2.0013.500TL, \%3.6 3.501 TL ve üstü olarak gruplanmışlardır. Çalışmada kıyı şeridinde yer alan donatı elemanları işlevsellik, sağlamlık, estetik, güvenlik, bakım, kullanım rahatlığl, çevreye uyum ve kent imajına katkı kriterleri açısından değerlendirilmiştir. Yapılan anket çalışmasından elde edilen sonuçlara göre genel olarak donatı elemanlarının aldıkları puan ortalamaları 2.65 (bilgilendirme ve yönlendirme levhaları-işlevsellik; çöp kutuları-kullanım rahatlığı) ile 3.70 (piknik masaları-çevreye uyum) arasında değişmektedir. Dolayısı ile tüm kent mobilyaları tüm kriterler açısından 'orta-iyi' düzeylerinde puan ortalamalarına sahiptir. Genel Memnuniyet Düzeyi en yüksek olan ilk üç donatı sırası ile piknik masaları (3.53), çiçeklikler (3.43) ve aydınlatma elemanları (3.24) olarak belirlenmiştir. En düşük memnuniyet ise çöp kutularına aittir (2.83). Kullanıcıların genel olarak memnuniyet düzeyleri 'orta' düzeyindedir. Ayrıca tüm donatı elemanlarının kriterler açısından değerlendirmesi yapılacak olursa; kent imajına katkı ve sağlamlık kriterleri (3.22) en yüksek puana sahip olup, bunu sırası ile estetik (3.19) ve çevreye uyum (3.17) kriterleri takip etmektedir. En düşük puan ise bakım kriterine aittir (2.84) (Çizelge 1). Kent mobilyaları genel olarak incelendiğinde; kentin odak noktasında yer alan bu rekreasyon alanlarında bulunan kent mobilyaları incelendiğinde; genel olarak konum, bakım, kullanım rahatlı̆̆ı ile ilgili birtakım problemlerinin mevcut olduğu, ancak pek çoğunun kent imajına katkı sağlayan bir yapı sergiledikleri görülmektedir ve bu durum elde edilen sonuçları destekler niteliktedir. Cinsiyet faktörü için yapılan $\mathrm{T}$ Testi sonucuna göre, kadınların beğeni düzeylerinin erkeklerden daha fazla olduğu ve bu farklılığın heykel ve plastik objeler için istatistiksel olarak anlamlı düzeyde olduğu görülmektedir. Yaş, meslek ve gelir faktörleri için yapılan Tukey testi 
sonuçları ise şöyledir: Yaş faktörü açısından; döşemeler, aydınlatma elemanları ve pergolalar için anlamlı, oturma elemanları ve piknik masaları için çok anlamlı bir fark bulunmaktadır. Piknik masaları için 46-65 yaş grubu bireylerin beğeni düzeyi, 17-36 yaş grubu bireylerden anlamlı derecede yüksektir. Oturma elemanları için ise 46 ve üzeri tüm yaş grubu bireylerin beğeni düzeyi 17-24 yaş grubu bireylerden anlamlı derecede yüksektir. Meslek açısından değerlendirme yapılacak olursa; çalışmayan bireylerin oturma birimleri için beğeni düzeyleri öğrencilere göre anlamlı derecede yüksektir. Gelir açısından istatistiksel açıdan anlamlı sayılabilecek bir fark görülmemiştir.

Çizelge 1. Donatı elemanlarının verilen kriterler açısından değerlendirme puanlarının ortalamaları

\begin{tabular}{|c|c|c|c|c|c|c|c|c|c|}
\hline & İşlevsellik & Sağlamlık & Estetik & Güvenlik & Bakım & $\begin{array}{l}\text { Kullanım } \\
\text { rahatlığı }\end{array}$ & $\begin{array}{l}\text { Çevreye } \\
\text { Uyum }\end{array}$ & $\begin{array}{c}\text { Kent } \\
\text { İmajına } \\
\text { Katkı }\end{array}$ & $\begin{array}{c}\text { Genel } \\
\text { memnun } \\
\text { iyet düz. }\end{array}$ \\
\hline Döșemeler & 3.25 & 3.20 & 3.30 & 2.85 & 2.80 & 2.95 & 3.20 & 3.00 & 3.07 \\
\hline Aydınlatma elemanları & 3.40 & 3.40 & 3.30 & 3.10 & 3.00 & 3.40 & 3.20 & 3.10 & 3.24 \\
\hline Açık oturma elemanları & 3.10 & 3.15 & 3.00 & 2.95 & 2.80 & 2.85 & 2.75 & 3.15 & 2.97 \\
\hline Çöp kutuları & 3.00 & 2.80 & 2.75 & 3.00 & 2.70 & 2.65 & 2.85 & 2.90 & 2.83 \\
\hline Bilgilendirme levhaları & 2.65 & 3.05 & 2.70 & 2.95 & 2.80 & 2.95 & 2.95 & 3.10 & 2.89 \\
\hline Heykel ve plastik objeler & 2.75 & 3.00 & 3.10 & 3.20 & 2.40 & 2.85 & 3.20 & 3.00 & 2.94 \\
\hline Pergolalar & 3.05 & 3.30 & 3.30 & 3.05 & 2.70 & 2.90 & 3.15 & 3.35 & 3.10 \\
\hline Çiçeklikler & 3.20 & 3.40 & 3.60 & 3.50 & 3.25 & 3.25 & 3.55 & 3.70 & 3.43 \\
\hline Piknik Masaları & 3.55 & 3.65 & 3.70 & 3.40 & 3.15 & 3.40 & 3.70 & 3.65 & 3.53 \\
\hline Ortalama & 3.11 & 3.22 & 3.19 & 3.11 & 2.84 & 3.02 & 3.17 & 3.22 & 3.11 \\
\hline
\end{tabular}

Çizelge 2. Anket katılımcılarının cinsiyet, yaş, meslek ve gelir durumlarına göre donatı elemanlarına verdikleri puanların Tukey ve T Testi ile değerlendirilmesi

\begin{tabular}{|c|c|c|c|c|c|c|c|c|c|c|}
\hline & & 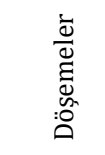 & 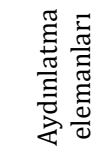 & 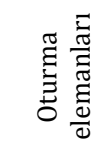 & 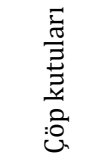 & 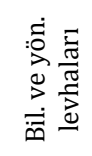 & $\begin{array}{l}\frac{\dot{0}}{\bar{d}} \\
\frac{\bar{d}}{\vec{d}} \\
\frac{0}{1}\end{array}$ & $\begin{array}{l}\frac{\pi}{\pi} \\
\frac{\pi}{0} \\
00 \\
\dot{0} \\
0\end{array}$ & 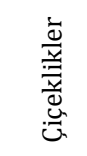 & 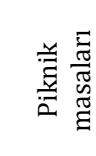 \\
\hline \multirow{3}{*}{ Cinsiyet } & Kadın & 3.13 & 3.21 & 3.29 & 2.95 & 2.84 & 2.98 & 3.36 & 3.62 & 3.49 \\
\hline & Erkek & 3.01 & 3.20 & 3.14 & 2.81 & 22.32 & 21.74 & 2.72 & 3.57 & 3.30 \\
\hline & P-değeri & 0.134 & 0.911 & 0.134 & 0.163 & 0.686 & $0.030^{*}$ & 0.324 & 0.660 & 0.052 \\
\hline \multirow{7}{*}{ Yaş } & $17-24$ & $0.03 \mathrm{AB}$ & $3.11 \mathrm{~B}$ & $3.08 \mathrm{~B}$ & 2.82 & 2.77 & 2.92 & $3.22 \mathrm{AB}$ & 3.53 & 3.31 \\
\hline & $25-36$ & $2.95 B$ & $3.21 \mathrm{AB}$ & $3.18 \mathrm{AB}$ & 2.82 & 2.67 & 2.7 & $3.18 \mathrm{~B}$ & 3.52 & $3.27 \mathrm{~B}$ \\
\hline & $37-45$ & $3.05 \mathrm{AB}$ & 3.10B & $3.14 \mathrm{AB}$ & 2.91 & 2.84 & 2.77 & 3.39AB & 3.54 & $3.45 \mathrm{AB}$ \\
\hline & $46-55$ & $3.38 \mathrm{~A}$ & $3.61 \mathrm{~A}$ & $3.66 \mathrm{~A}$ & 2.98 & 3.17 & 2.87 & $3.69 \mathrm{~A}$ & 4.01 & $3.83 \mathrm{~A}$ \\
\hline & $56-65$ & $3.38 \mathrm{~A}$ & $3.53 \mathrm{AB}$ & $3.68 \mathrm{~A}$ & 3.28 & 3.28 & 3.29 & $3.63 \mathrm{AB}$ & 3.80 & $3.84 \mathrm{~A}$ \\
\hline & 66 ve üstü & $3.62 \mathrm{~A}$ & $3.31 \mathrm{AB}$ & $3.66 \mathrm{~A}$ & 3.5 & 3.00 & 2.91 & $4.00 \mathrm{~A}$ & 3.97 & $3.44 \mathrm{AB}$ \\
\hline & P-Değeri & $0.026^{*}$ & $0.035^{*}$ & $0.004^{* *}$ & 0.335 & 0.152 & 0.439 & $0.015^{*}$ & 0.088 & $0.007^{* *}$ \\
\hline \multirow{8}{*}{ Meslek } & Öğrenci & 3.02 & 3.07 & $3.01 \mathrm{~B}$ & 2.74 & 2.74 & 2.84 & 3.22 & 3.50 & 3.31 \\
\hline & Memur & 3.21 & 3.46 & $3.42 \mathrm{AB}$ & 3.01 & 3.01 & 2.80 & 3.51 & 3.73 & 3.38 \\
\hline & İşçi & 3.15 & 3.40 & $3.29 \mathrm{AB}$ & 3.08 & 2.83 & 3.17 & 3.51 & 3.58 & 3.40 \\
\hline & İşsiz & 2.96 & 3.23 & $3.67 \mathrm{~A}$ & 3.08 & 2.81 & 2.48 & 3.07 & 3.59 & 3.63 \\
\hline & Emekli & 3.23 & 3.42 & $3.48 \mathrm{AB}$ & 3.13 & 2.82 & 2.92 & 3.57 & 3.82 & 3.66 \\
\hline & Ev hanımı & 3.01 & 3.26 & $3.14 \mathrm{AB}$ & 2.84 & 2.92 & 3.11 & 3.26 & 3.56 & 3.47 \\
\hline & Özel Sektör & 3.07 & 3.20 & $3.30 \mathrm{AB}$ & 3.29 & 2.81 & 2.78 & 3.32 & 3.68 & 3.39 \\
\hline & P-Değeri & 0.691 & 0.156 & $0.007^{* *}$ & 0.314 & 0.903 & 0.398 & 0.252 & 0.670 & 0.532 \\
\hline \multirow{5}{*}{ Gelir } & 1000 TL ve altı & 3.00 & 3.15 & 3.10 & 2.81 & 2.77 & 2.91 & 3.23 & 3.54 & 3.38 \\
\hline & 1001-2000TL & 3.20 & 3.26 & 3.31 & 2.99 & 2.94 & 2.88 & 3.51 & 3.69 & 3.56 \\
\hline & $2001-3500 \mathrm{TL}$ & 3.02 & 3.33 & 3.32 & 2.85 & 2.76 & 2.64 & 3.22 & 3.54 & 3.23 \\
\hline & 3501TL ve üstü & 3.13 & 2.88 & 3.15 & 3.01 & 2.7 & 3.01 & 3.12 & 3.74 & 3.25 \\
\hline & P-Değeri & 0.198 & 0.244 & 0.223 & 0.485 & 0.646 & 0.333 & 0.074 & 0.557 & 0.105 \\
\hline
\end{tabular}

Ortak harfi olmayan ortalamalar Tukey testine göre farklıdır $(\mathrm{p}<0.05)$

\section{Tartışma ve Sonuç}

Donatı elemanları, kentsel mekanların en önemli bileșenlerinden olup, kentsel alan kullanımları içerisinde mekanlara estetik ve fonksiyonel açılardan anlam katan, tanımlayan, tamamlayan ve kullanışlı hale getiren elemanlardır. $\mathrm{Bu}$ nedenle donatı elemanlarının yeterli sayıda, dış etkenlere dayanıklı, kendisinden beklenen fonksiyonu doğru biçimde yerine getiren, kullanıcı beklentilerini karşılayan yapılarda olmasının yanı sıra kent kimliğine katkı sağlayan, çevresi ile bütünleșen ve uyum sağlayan özellikler sergilemesi, yaşanabilir çevreler oluşturmak adına önemlidir. Ayrıca pek çok dış etkene maruz kalan donatı elemanlarının doğru 
ve yeterli sayıda yerleştirilmesi ve bakımlı olması da gerekmektedir. Planlama çalışmalarından, tasarım, uygulama ve kontrol aşamasına kadar geçen süreçte doğal ve kültürel faktörler mutlaka göz önüne alınmalıdır. Başal ve ark. (1993)'nin belirttiği üzere donatı elemanları, kent disiplini, kent bütünlügüne yönelik görsel, simgesel işlevler taşımalı, mekan kolay algılanmalı, ekonomik olmalı ve her şeyden önemlisi iklim, mimari ve tarihsel çevreyle uyum içinde olmalıdır (Kuşkun, 2003; Özer ve ark., 2010). Kentleşme ve uygarlaşmanın çok hızlı bir şekilde geliştiği Türkiye'de sorun haline gelen kent bütünlüğünü tamamlayıcı öğeler olan kent mobilyaları iyi tanımlanmalı, kentsel çevre kalitesine olan olumlu katkıları göz ardı edilmemelidir. Kent mobilyaları, doğru zamanlarda, doğru yerlerde kullanılmalı, eğitimli ve uygar toplum olarak bu öğelere milli servet gözüyle bakılıp zarar görmemeleri için önlemler alınmalıdır (Akyol, 2006). Yapılan çalışmada Ordu kenti kıyı rekreasyon alanlarında bulunan donatı elemanlarının kullanıcılar açısından orta ve iyi düzeyde memnuniyet verdiği tespit edilmiştir. Genel olarak değerlendirildiğinde kent imajına katkı ve sağlamlık kriteri açısından en yüksek memnuniyet düzeyi gözlenmiş (iyi), bakım kriteri açısından en düşük memnuniyet düzeyi (orta) gözlenmiştir. Kötü ve çok kötü düzeyleri gözlenmemiş olup, kullanıcılar açısından bu düzeyde memnuniyet gözlenmesi, ümit verici olarak görülmektedir. Ancak iyi ve çok iyi düzeyde memnuniyet derecelerinin olması istenen bir durumdur. Bazı donatı elemanlarının özellikle alan içerisindeki konumları, miktarları, kullanışlılıkları ve bakımları açısından yetersizlikler tespit edilmiştir. $\mathrm{Bu}$ eksikliklerin giderilmesi ile memnuniyet düzeylerinin artacağı düşünülmektedir. Kentsel alan kullanımlarının genel olarak amacı kullanıcılarını estetik ve fonksiyonel açılardan mutlu etmek, onlara en iyi hizmeti vermektir. Donatı elemanları da bu genel amaca hizmet etmeli ve onları kullanan bireylerin her açıdan mutlu edici ve memnuniyet verici olmasını sağlamalıdır.

\section{Kaynaklar}

ADNKS 2017. Türkiye İstatistik Kurumu, Adrese Dayalı Nüfus Kayıt Sistemi (ADNKS) Veri Tabanı.

Akyol, E. 2006. Kent Mobilyaları Tasarım ve Kullanım Süreci. İstanbul Teknik Üniversitesi Fen Bilimleri Enstitüsü, Yüksek Lisans Tezi.

Başal, M., Memlük, Y., Yılmaz, O., 1993. Peyzaj Konstrüksiyonu. Ankara Üniversitesi Ziraat Fakültesi Peyzaj Mimarlığı Bölümü, 170, Ankara.

Bayrakçı, O., 1991. Kent Mobilyaları Tasarımında Kimlik Sorunu ve Kent Kimliği İçindeki Yeri. Kamu
Mekanları Tasarımı ve Kent Mobilyaları Sempozyumu. Mimar Sinan Üniversitesi Mimarlık Fakültesi, 75-77, İstanbul.

Bayraktar, N., Tekel, A., Ercoşkun, A. Y., 2007. Ankara Atatürk Bulvarı üzerinde yer alan kentsel donatı elemanlarının sınıflandırılması, değerlendirilmesi ve kent kimliği ilișkisi. Gazi Üniv. Mühendislik Mimarlık Fakültesi Dergisi. 23(1): 105-118.

Bulut, Y., Atabeyoğlu, Ö., 2007. Fountains as urban furniture in historical urban structure and usage culture: Erzurum city case. Building and Environment, 42 (6): 2432-2438.

Bulut, Y., Atabeyoğlu, Ö., Yeşil, P., 2008. Erzurum Kent Merkezi Donatı Elemanlarının Ergonomik Özelliklerinin Değerlendirilmesi Üzerine Bir Araştırma. Tarım Bilimleri Dergisi, 14 (2): 131-138.

Çoban, E., Demir, Z., 2014. Kent mobilyalarının bulundukları mekânlara etkileri: Düzce örneği. Düzce Üniv. Bilim ve Teknoloji Dergisi, 2: 128-140.

Çubuk, M., 1991. Kamu Mekanları ve Kentsel Tasarım. Kamu Mekânları Tasarımı ve Kent Mobilyaları Sempozyumu. Mimar Sinan Üniversitesi Mimarlık Fakültesi, İstanbul.

Erdoğan, E., 2006. Çevre ve Kent Estetiği. ZKÜ Bartın Orman Fakültesi Dergisi. 8 (9): 68-77.

Erdoğan, R., Oktay, H. E., Yıldırım, C., 2011. AntalyaKonyaaltı parklarında kullanılan donatı elemanları tasarımlarının kullanıcı görüşleri doğrultusunda değerlendirilmesi. Artvin Çoruh Üniversitesi Orman Fakültesi Dergisi, 12 (1): 1-8.

Gül, A., Küçük, V., 2001. Kentsel açlk-yeșil alanlar ve Isparta Kenti örneğinde irdelenmesi. Süleyman Demirel Üniv. Orman Fakültesi Dergisi 2: 27-48.

Kuşkun, P., Yılmaz, H., 2003. Erzurum kent bütününde donatı elemanlarının kullanımı üzerine bir araştırma. Atatürk Üniversitesi Ziraat Fakültesi Dergisi, 34(4): 345-351.

Özer, S., Aklıbaşında, M., Zengin, M., 2010. Erzurum Kenti Örneğinde Kullanılan Kuşatma Elemanlarının Kent İmajı Üzerindeki Etkileri. Tekirdağ Ziraat Fakültesi Dergisi; 7(2): 123-130.

Sha-jun, L., Zu, Y., Yu-tao, F., Fu-chang, Z., 2005. A Survey of Humanized Design of Urban Outdoor Furniture. Journal of Southern Yangtze University

Yıldızcı, A.C., 2001. Kent mobilyaları kavramı ve İstanbul'daki kent mobilyalarının irdelenmesi, 1.Uluslararası Kent Mobilyaları Sempozyumu, İstanbul.

Yılmaz, H., Yılmaz, S., 1997. Kimlikli Kentleşmede Peyzaj Planlaması. Ankara Sempozyumu, Ankara. 